\section{5. アルカリフォスファターゼアイソザイム*}

緒言

血清アルカリフォスファターゼ (ALP) の測定は, 肝 ・胆道疾患扔よび骨疾患の診断に久くことのできない検 查法であり，日常臨床上広く行なわれている。ささらに， そのアイソザイムの分析に上り，血清 ALP には臓器由 来を異にするALP のあることが明らかにされ，ALP ア イソザイム検査に上り，更に臨床的意義は拡大されてい る・癌の診断については, 転移性肝癌あるいは骨腫瘍に おいて血清 ALP が著明に上昇することが古くから知ら れていたが，1968年，Fishman らが癌細胞に由来し， 胎盤 ALP と同じ性質を有する Regan isoenzyme を報告 して以来, 改めて注目される上らになった。 その後, 中 山ら ${ }^{2)}$ がNagao isoenzyme, 屯た Warnock ら ${ }^{32}$ がへパ トームに特異的に出現する variant ALP などを報告し ている.

ここではわれわれの成續を中心として，血清 ALP ア イソザイム呿よびその癌診断に和ける意義について報告 する・

$$
(-)
$$

$(+)$

$A L P_{1}$ and $A L P_{2}$

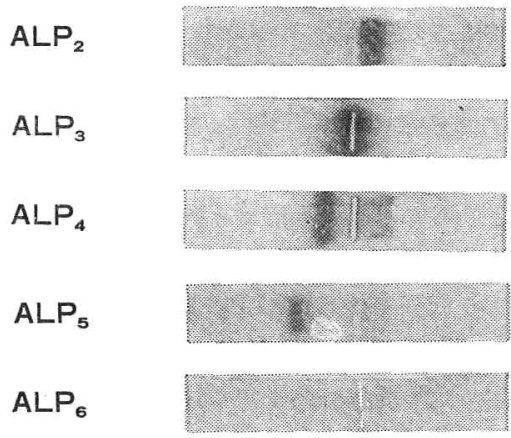

I. 血清アルカリフォスファターゼ アイソザイムについて

血清 ALP のザイモグラムは寒天ゲル，七ルロゲルを 支持体とした場合と即粉げルを支持体とした場合で異な っている。また，ポリアクリルアマイドディスク電気泳 動法は殷粉ゲルと同じザイモグラムを示す.

寒天ゲルとポリアクリルアマイドディスク電気泳動法 の血清 ALP ザイモグラムを Fig. 1 に示した. 寒天ゲ ルでは $\mathrm{ALP}_{1}$ から $\mathrm{ALP}_{6}$ までの 6 つに分離され, ディス ク電気泳動法では ALP Iから ALP VII までの 7 つに分 離された。

$\mathrm{ALP}_{2 \sim 6}$ は ALP II〜VI 亿それぞれ一致している. また，ALP 1 はALP VII に一致している.ALP VII は 原点に留まるALPであり，このALP は後述の如く， 高分子 ALP であるのでディスク電気泳動法では分子 篩効果が大きいため原点に留まると考学られる.ALP I は寒天ゲル法では検出されない，これは $\mathrm{ALP}_{1}$ と電気的 易動度が涪涪等しいため分別できないためと考えてい

Fig. 1. Serum ALP zymogram, left side : agar gel electrophoresis, right side : polyacrylamide gel disc electrophoresis.

* Alkaline phosphatase isoenzymes.

** Hiroshi Suzuki, Shiro Iino, 東京大学医学部第 1 内科学教室. 
Table 1. The tissue origins and clinical significances of serum ALP isoenzymes.

\begin{tabular}{c|c|c|l}
\hline \hline Agar gel & PAGD & Origin & \multicolumn{1}{|c}{ Clinical significance } \\
\hline 1 & VII & $\begin{array}{l}\text { Liver(high } \\
\text { molecular) }\end{array}$ & $\begin{array}{l}\text { Obstructive jaundice } \\
\text { Space-occupying lesion }\end{array}$ \\
\hline 2 & I & Hepatoma & Hepatoma (30\%) \\
\hline 3 & II & Liver & Hepato-biliary diseases \\
\hline 4 & IV & $\begin{array}{l}\text { Placenta } \\
\text { Cancer }\end{array}$ & Pregnancy cancer (<1\%) \\
\hline 5 & V & Intestine & $\begin{array}{l}\text { B and O blood group } \\
\text { (secretor status) Liver } \\
\text { cirrhosis (40\%) }\end{array}$ \\
\hline 6 & VI & Liver & Ulcerative colitis (20\%) \\
\hline
\end{tabular}

PAGD : polyacrylamide gel disc.

Table 2. Enzymological and immunological properties of tissue alkaline phosphatases.

\begin{tabular}{l|c|c|c|c}
\hline \hline & Liver & \multicolumn{2}{|c|}{ Bone } & \multicolumn{2}{|c|}{ Placenta } & Intestine \\
\hline Inhibitors & & & & \\
L-phenylalanine & - & - & + & + \\
L-homoarginine & + & + & - & - \\
Urea & + & + & + & + \\
Heat-stability & & & & \\
$56^{\circ} \mathrm{C}, 15 \mathrm{~min}$. & + & + & - & + \\
$\quad 65^{\circ} \mathrm{C}, 10 \mathrm{~min}$. & + & + & - & + \\
Neuraminidase* & + & + & + & - \\
Immunological & & & & \\
$\quad$ reaction & & & & \\
$\quad$ Anti liver ALP & + & + & - & - \\
Anti placental ALP & - & - & + & + \\
Anti intestinal ALP & - & - & + & + \\
\hline
\end{tabular}

* Changes of electrophoretic mobility.

る. 従って, 高分子 ALP $\left(\mathrm{ALP}_{1}\right)$ の検出には寒天ゲル 法が, ALP I の検出にはディスク電気泳動法が適して物 り，両法を併用する必要がある。

血清 ALP アイソザイムの臨床的意義抢よび臟器由来 のまとめを Table 1 亿示した.4,5)

$\mathrm{ALP}_{2}$ (ALP II) は肝 ALP, $\mathrm{ALP}_{3}$ (ALP III) は骨 ALP, $\mathrm{ALP}_{4}$ (ALP IV) は胎盤 ALP, $\mathrm{ALP}_{5}$ (ALP V) は，小腸 ALP と電気的易動度拈よび醭素学的性質が一 致している. ALP 6 (ALP VI) は，潰瘍性大腸炎の活 動期に出現するが，正常に存在する $\mathrm{ALP}_{2}$ が何等かの修 飾を受けてその電気的易動度を変えたものである. ${ }^{6}$

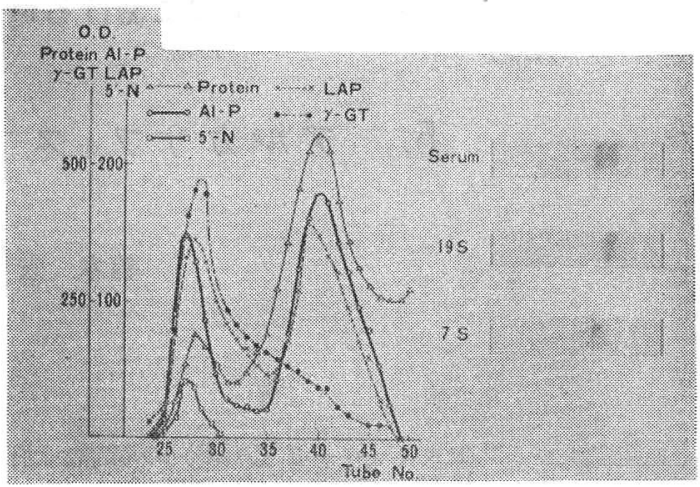

Fig. 2. High molecular biliary tract enzymes.

これら ALP アイソザイムの血中の上昇機序は，その 臓器に和けるALP の生成充進を反映している点が，い わゆる血清遊出酵素とは異なる点である.

われわれは現在までに, 肝, 胎盤䟥よび小腸 ALP の 精製化成功しているが, 骨 ALPを加竞たこれら藏器 ALP の醭素学的性質のまとめ范 Table 2 に示した。こ の成績からみると肝と骨, 胎盤と小腸 ALPは, それぞ れ近い関係にあることが認められる。

癌の診断と関係があるのはALP ${ }_{1}, \mathrm{ALP}_{3}$ (ALP III), $\mathrm{ALP}_{4}$ (ALP IV) 拉よびALPIである.

\section{II. $\mathrm{ALP}_{1}$ (高分子 ALP) について}

$\mathrm{ALP}_{1}$ は肝癌, とくに 転移性肝癌に高率に出現が認め られる。明渡らは $\mathrm{ALP}_{1}$ は肝癌細胞に由来する可能性を 考えている。しかし，われわれは $\mathrm{ALP}_{1}$ が肝癌だけでな く, 肝膿瘍などの肝癌以外の限局性肝障害㔚よび閉塞性 黄疾でも高率に出現を認めている.4) また， Sephadex G-200 ヒよるゲル沪過により ALP 1 は 19 S 分画隹認めら れ, 同時にこの分画に 5'-ヌクレオチダーゼ $\left(5^{\prime}-\mathrm{N}\right)$, 口 イシンアミノペプチダーゼ (LAP), $ケ$ ル゙ルタミルトラ ンスペプチダーゼ $(\gamma$-GTP) などのいわゆる胆道系醭素 も認めら机る (Fig. 2). ") 従って, ALP 1 は高分子 ALP であると同時に, 胆道系酳素と同一の機序によって血中 に上昇すると考光られる。慗た， $\mathrm{ALP}_{1}$ はnーブタノール 処理により低分子化し, $\mathrm{ALP}_{2}$ と同心゙電気的易動度を示 す.また, 肝癌組織の ALP を組織化学的に検索すると， ALP 活性は, 肝癌細胞よりも周囲の肝組織中に著明な 活性が認められる。これは肝癌により周囲の肝組織が圧 迫され，部分的な胆管閉塞が起り，それより末梢の肝細 胞に拉いて ALP の生成九准が起るとともに, 䏣管から 晹管への排泄障害により,ALP 活性が增加すると考えて いる.これらの成績を総合すると $\mathrm{ALP}_{1}$ は肝癌細胞に由 
来するのではなく, 閉塞性黄疸と同様の機序で肝細胞の 毛細胆管側絨毛に局在する $\mathrm{ALP}_{2}$ が膜破片の形で血中に 出現するため, 高分子 ALP として検出されると考兄ら れる。

\section{III. $\mathrm{ALP}_{3}$ (骨性 ALP) について}

癌の骨生成性骨転移では, 血清 ALP が著明に上昇す るが，これは $\mathrm{ALP}_{3}$ の増加によるものである. しかし， $\mathrm{ALP}_{3}$ の増加は癌だけでなく, 乳・幼児, 骨生成の亢進 のみられる骨疾患でも同様に $\mathrm{ALP}_{3}$ の増加がみられる. 従って $\mathrm{ALP}_{3}$ の増加は癌細胞由来の ALP によるもので はなく，骨生成の亢進を反映したものであると考学られ る.な拉, 北村らは, 乳・幼児期にみられる血清 $\mathrm{ALP}_{3}$ と癌の骨転移にみられる血清 $\mathrm{ALP}_{3}$ とは, 電気的易動 度に多少の差がみられるとしているが，われわれはまだ その様な例を経験していない. 癌の骨転移にみられる $\mathrm{ALP}_{3}$ が骨 ALP と異なるかどうかは更に検討する必要 があると考光られる。

\section{IV. $\mathrm{ALP}_{4}$ (胎盤 $\left.\mathrm{ALP}\right)$ について}

妊娠末期に血清中に出現する $\mathrm{ALP}_{4}$ は胎盤 ALP と電 気的易動度括よび醭素学的性質が一致して掠り, 胎盤で の ALP 生成え進を反映して，血中に増加したと考えら れる.

Fishman らは Regan という肺癌患者の血清㘧よび癌 組織中に胎盤 ALP と同じ酵素学的性質を有する ALP を認め, Regan isoenzyme として報告した. ${ }^{1}$ われわれ もほぼ同時期に一部の癌患者血清中に $\mathrm{ALP}_{4}$ の出現を認 めたが, 同時に重症非癌疾患にも $\mathrm{ALP}_{4}$ の出現を認め,

重症疾患にみられる $\mathrm{ALP}_{4}$ として報告した.4) $\mathrm{ALP}_{4}$ は $65^{\circ} \mathrm{C}$ ひ失活しないといら耐熱性を有しているので，耐 熱性 ALP として測定すると，悪性腫瘍患者の約20\%に 出現が認められた。しかし，われわれは，当時，わが国 で使用されているアルブミン製剤の使用例に $\mathrm{ALP}_{4}$ が血

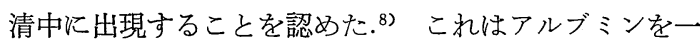
部胎盤血から精製しているため, 胎盤 ALP がアルブミ ソ製剤中に入るためである. 従ってアルブミン製剤使用 例では，そのために $\mathrm{ALP}_{4}$ が血中に出現する可能性があ る・癌患者の多くはアルブミン製剤の投与を受けている ため, 正確な癌由来の $\mathrm{ALP}_{4}$ の出現頻度を算出すること はできなかった。一方，中山ら²は Regan isoenzyme と Lーロイシンに対する感受性の異なる癌由来の ALP の出 現を認め, Nagao isoenzyme として報告している。われ われは癌患者血清中からは Nagao isoenzyme を証明す ることはできなかったが, 妊婦 200 例の血清中 1 例に
Nagao isoenzyme と同じ性質を有するALP を認めた. この ALP の電気的易動度は, 通常の胎盤 ALP に比べ て寒天ゲル法では，やや陽極寄りに泳動された.8) 中山 らの好意により分与を受けた Nagao isoenzyme 执よび Regan isoenzyme は胎盤 ALP の radioimmunoassay に より胎盤 ALP と同一の dose response curveを示し, 免疫学的には同一であることを認めた。な和 Inglis ら は Nagao isoenzyme は胎盤 ALPの D-variantであると している.

癌患者に癌由来の ALP が血中に出現する頻度は極め て低く，1\%以下であると考光られる。したがって，臨 休的意義は大きいとはい光ない。しかし, 癌由来の ALP が胎艋 ALP と酵素学的にも免疫学的にも同一であるこ とは, 癌化とALP の関係を研究する上には重要な所見 であり, carcinoplacental enzyme の1つであるとい党 る.

\section{ALP I (Hepatoma ALP) について}

Warnock $ら^{32}$ は, ヘパトーム患者の癌組織执よび血清 中に特異な ALP の出現を認め, 肝 ALP の variant であ ると考光，variant ALP として報告した。われわれは ヘパトームに特異的に出現するので hepatoma ALP と 呼んでいる. われわれの hepatoma ALP の成績は， Table 3 亿示すと拉りである.10) ヘパトームの約30\%に 出現が認められ，その他の疾患では，尿毒症に一過性の 出現をみた浮かは現在まで 1 例も認めていない。 $\alpha$-フェ トプロテイン (AFP) との関係をみたのが Table 4 であ る. AFPの出現していないーパトーム4 例中 2 例に出現 を認めている。また, AFP の出現を認めたへパトブラス トームおよび胎児性腫瘍では hepatoma ALP は 1 例も 出現を認めていない.これらの成績は AFP と hepatoma ALP は生成機序が異なることを示すとともに，AFP

Table 3. Prevalence of hepatoma ALP.

\begin{tabular}{l|c|c}
\hline \multicolumn{1}{c|}{ Diseases } & $\begin{array}{c}\text { Number } \\
\text { of cases }\end{array}$ & $\begin{array}{c}\text { Hepatoma } \\
\text { ALP }\end{array}$ \\
\hline Hepatoma & 51 & $16(31 \%)$ \\
Hepatoblastoma & 3 & 0 \\
Embryonal cancer & 2 & 0 \\
Congenital bile duct atresia & 5 & 0 \\
Other cancers & 76 & 0 \\
Liver cirrhosis & 90 & 0 \\
Other diseases & 220 & 1 (Uremia) \\
Healthy adults & 235 & 0 \\
\hline
\end{tabular}


Table 4. $\alpha$-fetoprotein, hepatitis B antigen and hepatoma ALP.

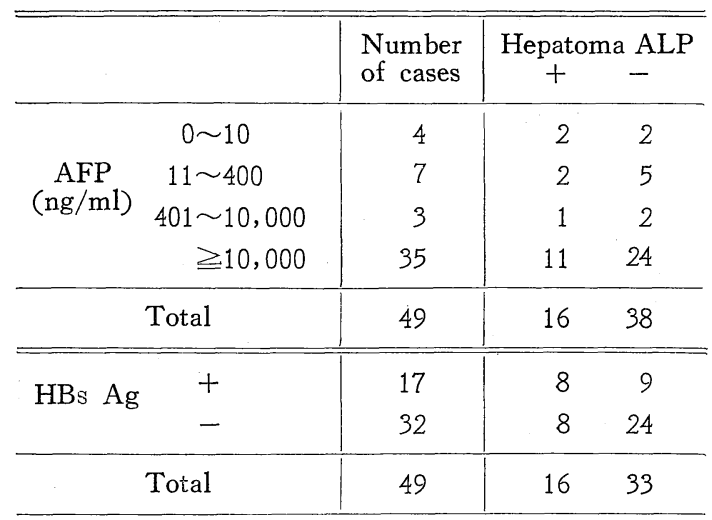

比ベると，ヘパトームに护る出現頻度は低いが，へパ トームの診断にある程度役立つことを示すものである.

Hepatoma ALPは, 組織化学的検索では, ヘパトー ム細胞の細胞質内に認められた。また, hepatoma ALP は電気的易動度特よび 耐熱性以外は Nagao isoenzyme に類似して怙り, 免疫学的には胎盤性 ALP と同一であ った. 東野ら ${ }^{11)}$ は羊膜の株化細胞の 1 つである FL 細胞 の ALPのうち, fast moving band の ALP (FL-ALPF) が酵素学的にも免疫学的にも hepatoma ALP と同一で あることを認めている. したがって, hepatoma ALP む 広い意味では carcinoembryonic enzyme の1つである といえる・

\section{結 論}

1. 肝癌では高分子 ALP，骨生成性骨転移では骨
ALP，一部の癌患者では胎盤 ALP 预よびヘパトームで hepatoma ALP が血中に増加する.このらち, 癌細胞に 由来するものは後二者のみである.

2. 癌患者の $1 \%$ 以下に癌組織由来の胎盤型 ALP で ある Regan isoenzyme および Nagao isoenzyme が血中 に出現する. しかし, その出現頻度は低く臨床的意義は 少ない。

3. ヘパトーム患者の約 $30 \%$ そパトーム組織由来の ALP の出現が認められ, ヘパトームに比較的特異的に 出現する.この ALP も広義の carcinoplacental ALP の 1つである。

\section{引用 文 献}

1) Fishman, W.H. et al. : Cancer Res., $28: 150$, 1968.

2) Nakayama, T. et al. : Clin. Chim. Acta, 30 : 546, 1970.

3) Warnock, M.L. and Reisman, R. : Clin. Chim. Acta, 24 : 5, 1969.

4) Suzuki, H. et al. : Ann. N. Y. Acad. Sci., 166 : $811,1969$.

5）飯野四郎他：生物物理化学, $19: 35,1974$.

6）三木一正他：日消誌，73:162，1976.

7) 鈴木 宏, 堺 隆弘：日消誌, 69:865, 1972.

8) Iino, S. et al. : Tumor Res., $8: 146,1973$.

9) Inglis, N.R. et al. : Cancer Res., $33: 1657$, 1973.

10) Suzuki, H. et al. : Ann. N. Y. Acad. Sci., 295 : 307, 1975.

11) Higashino, K. et al. : Ann. N. Y. Acad. Sci., $295: 337,1975$. 